\title{
Indian company offers cheap anti-AIDS drugs
}

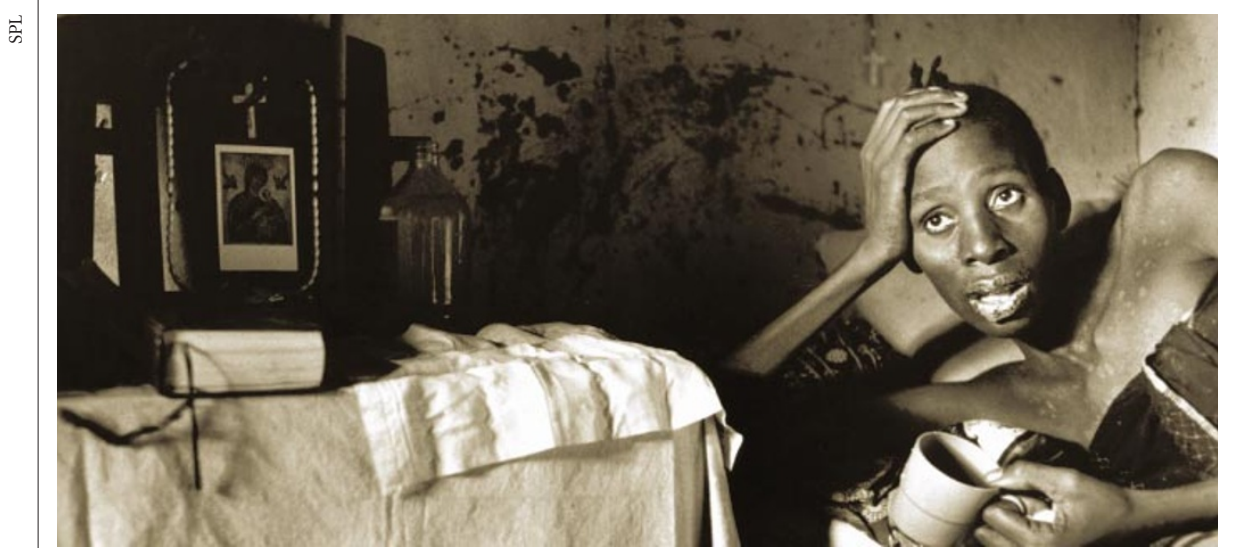

Some hope: but Western pharmaceutical companies are expected to block the cut-price drugs.

\section{David Dickson}

An Indian drug company has offered to supply a triple-drug anti-AIDS 'cocktail' to sufferers in developing countries at less than one-twentieth of the standard cost in the West.

Cipla of Mumbai says it has developed its own methods for producing the three drugs - stavudine, lamivudine and nevirapine thereby avoiding the process patents owned by the major manufacturers in India.

The company says it will supply a combination of the drugs to the French charity Médecins sans Frontières (Doctors without Borders) for $\$ 350$ a year per patient, on condition that the organization provides the treatment free to patients.

Cipla has also offered the combination directly to wholesalers at $\$ 1,200$ and to governments at $\$ 600$ a year. "We're not making money, but we are not going to lose money either, since with the average of the three prices we should break even," Yusuf Hamied, the chairman of Cipla, told The Times of India last week.

Hamied said the move was inspired by the suffering caused by the recent earthquake in Gujarat, and predicted that AIDS was going to be "a bigger holocaust in India than the earthquake".

The action is being seen as a bid to force the major producers of anti-AIDS drugs to reduce their prices in developing countries to an affordable level. But it could fall foul of allegations of patent infringement. At present, the standard annual cost of the triple therapy in the United States and Europe is between $\$ 10,000$ and $\$ 15,000$.

Last year, the five leading drugs manufacturers agreed through the World Health Organization to negotiate with individual countries on a preferential pricing strategy. Deals have already been reached with Uganda, Senegal and Rwanda. Although no prices have been released, a figure of $\$ 1,000$ for annual treatment has been reported for Senegal.
Bristol-Myers Squibb, GlaxoSmithKline (created last December from a merger between Glaxo Wellcome and SmithKline Beecham) and Boehringer-Ingelheim are the main manufacturers and patent holders of

\section{Quirin Schiermeier}

Melting permafrost in Arctic regions is likely to accelerate global warming, as well as disrupting the lifestyle of indigenous people, researchers warned last week's meeting of the United Nations Environment Programme (UNEP) in Nairobi.

A seventh of the Earth's carbon is stored in frozen Arctic soil, the scientists say, and huge amounts of greenhouse gases will be released into the atmosphere if rising temperatures cause the permafrost to melt and its organic material to be broken down by bacteria.

"There is now evidence that the permafrost in some areas is starting to give back its carbon," Svein Tveitdal, director of UNEP's Global Resource Information Database in Arendal, Norway, told a meeting of UNEP's governing council.

Tveitdal also pointed to regional problems likely to be caused in Siberia, Scandinavia, northern Canada and Alaska by melting permafrost, which can trigger subsidence and damage buildings.

UNEP scientists fear that rising temperatures and melting of the permafrost may have an impact on Arctic wildlife such as reindeer, and on the traditional lifestyle of indigenous people in northern regions.

"In Canada's north, we are seeing dramatic changes that affect permafrost and sea ice, the latter of which has major implications for species on which the traditional Inuit life depends, such as polar bears and seals," said David Anderson, Canada's environment minister and the three drugs. Although the companies have made no public comment on Cipla's move, they are expected to vigorously oppose what they will regard as an attempt to undermine their drug patents.

Last December, for example, Cipla stopped importing its own low-cost combination of the anti-AIDS compounds lamivudine and zidovudine into Ghana after being warned by Glaxo Wellcome that it was infringing the company's patent rights.

Cipla's offer is already being used by the British aid charity Oxfam to highlight what it describes as an "undeclared drugs war" by the pharmaceutical industry and governments of rich nations against the world's poor.

On Monday, the charity announced the launch of a campaign in which it is demanding that companies contribute a percentage of the profits from any drugs which earn more than US $\$ 1$ billion per year to a research fund for diseases that afflict poor people.

\section{Fears grow over melting permafrost}

president of UNEP's governing council.

Delegates at the meeting criticized the lack of a unanimous political response to global climate change. "We are taking action domestically, but we need awareness and movement on the international front as well," Anderson said.

The UNEP governing council is the main international forum for governments to address environmental policy issues. The meeting was attended by environment ministers from over 100 nations, along with scientists and representatives of nongovernmental organizations and corporations.

Klaus Töpfer, executive director of UNEP, told the meeting that the time for talk had ended, and the time had come for delivering environmental action. "We do not need new priorities or new visions," he told the Nairobi meeting. "What we need to do now is to implement."

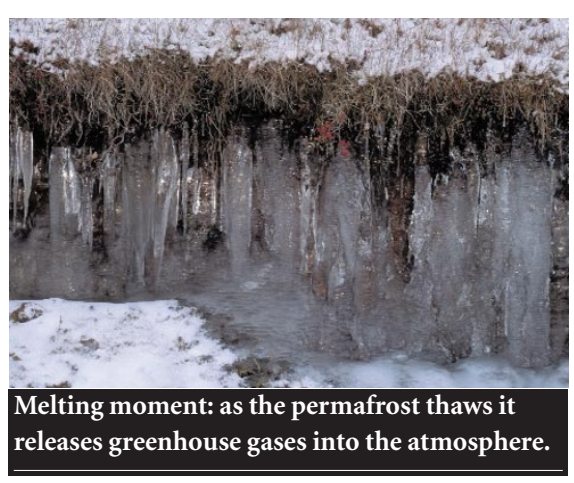

